\title{
Modulation of cell proliferation and differentiation of human lung carcinoma cells by the interferon-alpha
}

\author{
Daniela Krejčová ${ }^{1}$, Jiřina Procházkovát ${ }^{1,2}$, Lukáš Kubala ${ }^{1}$ and Jiří Pacherník ${ }^{2}$ \\ ${ }^{1}$ Institute of Biophysics, v.v.i., Academy of Sciences of the Czech Republic, Královopolská 135, 61265 Brno, Czech Republic \\ ${ }^{2}$ Institute of Experimental Biology, Department of Physiology and Immunology of Animals, Faculty of Science, Masaryk \\ University, Kotlárská 2, 61137 Brno, Czech Republic
}

\begin{abstract}
Treatments of non-small cell lung cancer (NSCLC), the most common form of lung cancer, still remain poor. Interferon alpha (IFN- $\alpha$ ), an important physiological immunomodulator, possesses direct cytotoxic and cytostatic effects on tumour cells, antiangiogenic effects, and activates anti-tumour immunity. Recently, the IFN- $\alpha$ oncologic indications have included melanoma, renal carcinoma, and different types of leukaemia. However, the application of IFN- $\alpha$ in therapy of lung cancer has not been validated yet. Herein the human lung carcinoma cell line A549, a model of NSCLC in vitro, was used to pursue the effect of IFN- $a$ on A549 cell proliferation and differentiation together with the effect on protein expression and activity of three ATP-transporters mediating multi-drug resistance (MDR). IFN-a significantly inhibited the proliferation of A549 cells which was not connected with arrest in a particular cell cycle phase. Further, IFN- $\alpha$-mediated differentiation of A549 was observed based on an increase in alkaline phosphatase activity. Simultaneously, IFN- $\alpha$ increased the expression and activity of ATP-transporters mediating MDR. Thus, the IFN- $\alpha$ down-regulation of NSCLC cell proliferation was accompanied by a potential of cells to exclude potential therapeutic substances such as chemotherapeutic agents. These effects could have a significant impact on considerations of IFN- $\alpha$ as a therapeutic agent for NSCLC.
\end{abstract}

Key words: Non-small cell lung cancer - ABC transporter proteins - Cell cycle - Interferons

\section{Introduction}

Lung cancer is a significant and widespread disease that constitutes a major public health problem worldwide (Hoang et al. 2002). The most common form of lung cancer is non-small cell lung cancer (NSCLC) that includes large cell lung cancer, squamous cell carcinoma and adenocarcinoma (Maione et al. 2004). Treatment outcomes for NSCLC still remain poor, although a number of biological agents, both single agents and combined with other conventional treatment modalities such as chemotherapy and radiotherapy, were evaluated (Hoang et al. 2002; Sandler 2003; Maione et al. 2004).

An important group of immunotherapeutics are interferons (IFNs). IFNs are naturally occurring cellular cytokines

Correspondence to: Lukáš Kubala, Institute of Biophysics, Academy of Sciences of the Czech Republic, Královopolská 135, 61265 Brno, Czech Republic

E-mail: kubalal@ibp.cz with important physiological functions in antiviral and antitumour defence (Jonasch and Haluska 2001; Antoniou et al. 2003). IFNs bind to cell surface receptors which, after oligomerisation, initiate a cascade of phosphorylation reactions in Janus kinases-signal transducers and activators of transcription (JAK-STAT) signalling intermediates, ultimately activating transcription of IFN-stimulated genes and corresponding cellular response (Caraglia et al. 2005). In the case of IFN- $a$, antitumour effects include direct cytotoxic and cytostatic effects on tumour cells, antiangiogenic effects, an increase in phagocytic activity of macrophages, and augmentation of the cytotoxicity of lymphocytes for target cells (Jonasch and Haluska 2001; Antoniou et al. 2003; Caraglia et al. 2005). Recently, the major oncologic indications for IFNs have included melanoma, renal cell carcinoma, AIDS-related Kaposi's sarcoma, follicular lymphoma, hairy cell leukaemia, and chronic myelogenous leukaemia (Jonasch and Haluska 2001). IFN- $\alpha$ has also been tested in therapy of lung cancer, particularly in combination with other treatments of small 
cell lung cancer (Zarogoulidis et al. 1996; Ruotsalainen and Mattson 2002). However, the trials were heterogeneous and overall conclusions from obtained data were inconsistent. To explain the discrepancies among inconsistent effects of IFN- $\alpha$ on lung cancer, it is essential to apprehend a direct modulation of cancer cell phenotype by IFN- $\alpha$. A better understanding of IFNs biology and interactions can improve application of these agents in the management of patients with cancer.

Herein, the human lung carcinoma cell line A549, a model of NSCLC in vitro (McCormick et al. 1995; Dohadwala et al. 2001; Lee et al. 2006), was used to pursue the effect of IFN- $\alpha$ on A549 cell proliferation and differentiation. Further, a protein expression and activity of three ATP-binding cassette $(\mathrm{ABC})$ transporters mediating multi-drug resistance (MDR) (Kvačkajová-Kišucká et a. 2001; Glavinas et al. 2004; Ozben 2006; Sarkadi et al. 2006) were also analysed. The results revealed a potential of IFN- $\alpha$ to decrease proliferation and induced differentiation of A549 cells. However, unpredictably, IFN- $\alpha$ increased protein expression of $A B C$ transporters.

\section{Materials and Methods}

\section{Materials}

The human lung carcinoma cell line A549 was obtained from ATCC (American type culture collection; Manassas, VA, USA). The cells were maintained in a DMEM (Dulbeco's modified Eagle's medium; PAN-Biotech GmBH, Aidenbach, Germany) supplemented with a $10 \%$ fetal bovine serum (PAN-Biotech $\mathrm{GmBH})$ and gentamycin (0.045 mg/l; Sigma-Aldrich, St. Louis, MO, USA). IFN- $\alpha$ isolated from human leukocytes (Alfaferone) was obtained from Alfa Wassermann S.P.A. (Pomezia, Italy).

\section{Cell viability}

The viability of cells was tested using the 2,3-bis(2-methoxy-4-nitro-5-sulfophenyl)-2H-tetrazolium-5-carboxanilide inner salt (XTT sodium salt) (Sigma-Aldrich), the determination of total whole cell lysate protein concentration using BCA (bicinchoninic acid) protein assay (Pierce, Rockford, IL, USA), direct counting of floating dead cells in media and staining of adherent A549 cell layer by trypan blue (Sigma-Aldrich) and positive cells as described previously (Frankova et al. 2006). The cells were seeded in 96-well plates for $4 \mathrm{~h}$ and consequently treated with IFN- $\alpha$ for 24,48 and $72 \mathrm{~h}$. The principle of the XTT colorimetric test is based on mitochondrial cleavage of the tetrazolium salt XTT to form a formazan soluble in aqueous solutions. This conversion occurs only in metabolic active cells. The absorbance was measured after $4 \mathrm{~h}$ at $450 \mathrm{~nm}$ against a reference wavelength $620 \mathrm{~nm}$, using a microtiter plate reader SLT Rainbow spectrophotometer (Tecan, Crailsheim, Germany).

\section{Determination of alkaline phosphatase (ALP) activity}

The activity of ALP, a marker of cell differentiation, was determined as described previously (Kovarikova et al. 2000). Briefly, the cells were seeded on 6-well plates in a density of $10 \times 10^{3} / \mathrm{cm}^{2}$ for $4 \mathrm{~h}$ and consequently treated with IFN- $\alpha$ for 24 or $48 \mathrm{~h}$. The cells were washed with Hank's buffered salt solution (HBSS) and frozen at $-80^{\circ} \mathrm{C}$. Then, $100 \mu \mathrm{l}$ of substrate buffer was added and the cells were scraped, lysed by sonication. The cell lysates were centrifuged for 15 min $\left(3000 \mathrm{rpm}, 4^{\circ} \mathrm{C}\right)$ and $50 \mu \mathrm{l}$ of ALP (4-p-nitrophenylphosphate) substrate was added to $50 \mu \mathrm{l}$ supernatant and incubated in 96 -well plate for $30 \mathrm{~min}$ at $37^{\circ} \mathrm{C}$. The reaction was stopped by adding $3 \mathrm{~mol} / \mathrm{l} \mathrm{NaOH}(50 \mu \mathrm{l} /$ well) and the optical densities were measured at $405 \mathrm{~nm}$ against a reference wavelength of $620 \mathrm{~nm}$.

\section{Flow-cytometric analyses of the cell cycle}

The determination was performed as described previously with modifications (Bryja et al. 2004). A549 cells were trypsinised, washed twice in phosphate buffered saline (PBS) and fixed in $70 \%$ ethanol at $-20^{\circ} \mathrm{C}$. After repeated washing in PBS, the cells were stained with propidium iodide diluted to $10 \mu \mathrm{g} / \mathrm{ml}$ in Vindelov's solution ( $1 \mathrm{mmol} / \mathrm{l}$ Tris- $\mathrm{HCl}, 1 \mathrm{mmol} /$ $1 \mathrm{NaCl}, 0.1 \%$ Triton X-100, $10 \mu \mathrm{g} / \mathrm{ml}$ RNase A, pH 8.0) for $30 \mathrm{~min}$ at $37^{\circ} \mathrm{C}$. The cell-cycle profile was determined with a FACSCalibur flow cytometer (Becton Dickinson, Franklin Lakes, NJ, USA) equipped with an argon-ion laser. CellQuest software running on an Apple Macintosh computer connected to the flow cytometer was used for the data acquisition. The cell-cycle phases were analysed with the aid of ModFit software (Verity Software House, Topsham, ME, USA).

\section{CD44 expression flow cytometric analysis}

The determination was performed as described previously with modifications (Bryja et al. 2004; Frankova et al. 2006). Briefly, the cells were seeded on $60 \mathrm{~cm}^{2}$ dishes in a concentration of $320 \times 10^{3}$ cells per well for $4 \mathrm{~h}$. IFN- $\alpha$ was added to the adhered cells in concentrations of 500, 1500 and $3000 \mathrm{U} / \mathrm{ml}$. After $48 \mathrm{~h}$ incubation the cells were washed and released from the surface with PBS+EDTA and washed with $\mathrm{PBS}+0.1 \%$ bovine serum albumin (BSA), centrifuged at $250 \times g$ for $10 \mathrm{~min}$ and diluted in PBS+0.1\% BSA to the concentration of $1 \times 10^{6}$ cells $/ \mathrm{ml}$. The cells were incubated with phycoerythrin (PE)-conjugated anti-CD44 monoclonal antibody or PE-conjugated IgG1 as isotype control $(10 \mu \mathrm{l}$ per vial with $200 \mu \mathrm{l})$ for $30 \mathrm{~min}\left(4^{\circ} \mathrm{C}\right)$ in dark, washed with PBS 
and cell surface expression of CD44 was determined with a FACSCalibur flow cytometer (Becton Dickinson). The geometric mean of the relative fluorescence unit of at least ten thousand cells was quantified using CellQuest software.

\section{Flow cytometric detection of ABC transporter activity}

$\mathrm{ABC}$ transporter protein activities were determined using fluorescent probes which are pumped out of the cell specifically by the given transporter protein (Orlický et al. 2004; Ozben 2006). Calcein-AM (calcein acetoxymethyl ester; Invitrogen, Carlsbad, USA), a substrate of both transporters ABCC1/multi-drug resistance protein-1 (MRP1) and ABCB1/MDR/P-glycoprotein (Pgp) was used. In live cells the nonfluorescent calcein-AM is converted to greenfluorescent calcein, after acetoxymethyl ester hydrolysis by intracellular esterases. Staining with calcein-AM $(0.2$ $\mu \mathrm{mol} / \mathrm{l}$ ) was performed in $\mathrm{HBSS}$ at $37^{\circ} \mathrm{C}$ for $30 \mathrm{~min}$ and the green fluorescence was detected by FACSCalibur (Becton Dickinson). Hoechst 33342 (Invitrogen) is a substrate of ABCG2/breast cancer resistant protein (BCRP). Staining with Hoechst $(5 \mu \mathrm{g} / \mathrm{ml})$ was performed in $\mathrm{HBSS}$ at $37^{\circ} \mathrm{C}$ for $90 \mathrm{~min}$ and the emitted fluorescence was detected by FACSVantage (Becton Dickinson). For the evaluation were used at least ten thousand morphologically normal cells characterised based on forward scattered light $v$ s. side scattered light properties. Inhibitors Sulindac $(20 \mu \mathrm{mol} / \mathrm{l}$; Sigma-Aldrich) and Fumitremorgin C (10 $\mu \mathrm{mol} / \mathrm{l}$; SigmaAldrich) were used to test the specificity of particular fluorescent dye for particular transporters (Rius et al. 2008).

\section{Western blotting analysis}

A549 cells were lysed in sodium dodecyl sulfate (SDS) lysis buffer consisting 1\% SDS, 50 mmol/l Tris- HCl, pH 7.5, 20\% glycerol, protease inhibitors cocktail (Sigma-Aldrich) and phosphatase inhibitor cocktail (PhosSTOP; Roche). The samples were boiled for $10 \mathrm{~min}$ and sonicated ( $5 \mathrm{~s}$, Sonifier B-12; Branson Ultrasonics Corp., Danbury, CT, USA). Protein concentration was determined using the DC protein assay kit (Bio-Rad Laboratories, Hercules, CA, USA). Lysates were supplemented with bromophenol blue $(0.01 \%)$ and $1 \% \beta$-mercaptoethanol and boiled for $5 \mathrm{~min}$. Equal amount of proteins (50 $\mu \mathrm{g}$ for determination of ABC transporters and $20 \mu \mathrm{g}$ for determination of phosphorylated and total levels of STAT-1, p38, $\beta$-tubulin and $\alpha$-actin) per sample were separated by SDSPAGE on $10 \%$ polyacrylamide gel and transferred to PVDF membranes (Immobilon Millipore, Bedford, MA, USA).

Western blotting was performed with the following primary antibodies: anti-phospho-p38 MAPK (Thr180/ Tyr182) (1:3000, 9215; Cell Signaling Technology, Danver, MA, USA), anti-phospho-STAT-1 (Tyr701) (1:5000, 9167; Cell Signaling Technology), anti-STAT-1 (1 : 3000,
9172; Cell Signaling Technology), anti-p38 (1 : 1000, sc7972; Santa Cruz Biotechnology, Santa Cruz, CA, USA), anti-ABCC1/MRP1 (1 :500, ALX-801-012; Alexis Corp., Lausen, Switzerland), anti-ABCB1/Pgp (1:100, 801004-C125; Alexis Corp.), anti-ABCG2/BCRP (1:500, sc-25822; Santa Cruz Biotechnology). The expression of a-tubulin (anti- $\alpha$-tubulin, $1: 2000$, sc-69969; Santa Cruz Biotechnology) or $\beta$-actin (anti- $\beta$-actin, 1 : 5000, A5441; Sigma-Aldrich) served as a control of equal loading of proteins. Horseradish peroxidase-conjugated anti-mouseIgG (NA931) and anti-rabbit-IgG (NA934) (Amersham Biosciences, Bucks, UK) were used as secondary antibodies. Detection was performed by ECL Plus Western blotting detection system (Amersham Biosciences) and radiographic films according to the manufacturer's instructions.

\section{Statistical analysis}

All values were reported as the means of four different experiments \pm SEM (standard error of the mean). The data were analysed using the Student's $t$-test for dependent samples using Statistica for Windows 8.0 (StatSoft, Inc., USA). $p \leq$ 0.05 was considered significant.

\section{Results}

Activation of intracellular signalling pathways STAT-1 and p38 in A549 cells by IFN- $\alpha$

The capacity of A549 cells to respond to IFN- $\alpha$ was tested by determination of specific signalling pathways activation. Phosphorylation of STAT- 1 and p38 mitogen activated kinase in A549 cells in response to IFN-a (range of concentrations from 500 to $3000 \mathrm{U} / \mathrm{ml}$ ) was analysed 15 and $30 \mathrm{~min}$ after the treatment. IFN- $\alpha$ induced concentration-dependent phosphorylation of both STAT-1 and p38 kinase (Fig. 1). Further, long-term effects of IFN- $\alpha(3000 \mathrm{U} / \mathrm{ml})$ on phosphorylation and total protein levels of STAT- 1 and p38 kinase were evaluated. Interestingly, IFN- $\alpha$ induced phosphorylation of both STAT- 1 and p38 kinase at all evaluated time intervals up to $72 \mathrm{~h}$. This effect was accompanied by increases in STAT- 1 total protein levels in the IFN-a treated cells and by increases in p38 kinase total protein levels during the incubation of cells independently on IFN- $\alpha$ treatment (Fig. 2).

\section{IFN- $\alpha$ significantly reduced proliferation of A549 cells}

The effect of IFN- $\alpha$ on A549 cell proliferation was tested by various methods. The evaluation of A549 proliferation based on determination of metabolic activity (Fig. 3A) and based on determination of total cellular protein mass (Fig. 3B) 


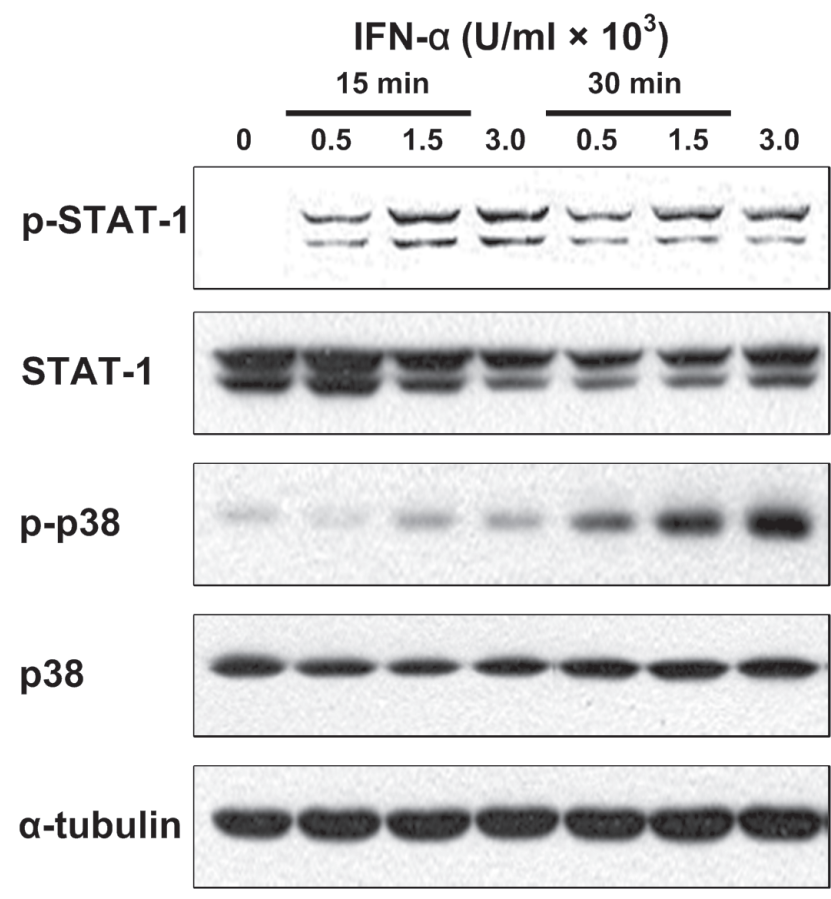

Figure 1. Dose-dependent phosphorylation of STAT-1 and p38 kinase after incubation of A549 with IFN- $\alpha$. A549 cells were seeded $4 \mathrm{~h}$ before IFN- $\alpha$ treatment and were treated with 500, 1500, and $3000 \mathrm{U} / \mathrm{ml} \mathrm{IFN}-\alpha$ for 15 and $30 \mathrm{~min}$. Both phosphorylated (p-STAT1 and p-p38) and total (STAT- 1 and p38) levels of STAT- 1 and p38 kinase together with levels of $\alpha$-tubulin were determined. Representative results from two independent experiments are shown.

showed significant reduction of proliferation after 24, 48 and $72 \mathrm{~h}$ of incubation. All tested concentrations of IFN- $\alpha$ ( 500 to $6000 \mathrm{U} / \mathrm{ml}$ ) revealed similar inhibitory effects up to incubation for $72 \mathrm{~h}$. Examination of cell morphology did not reveal any changes specific for apoptotic or necrotic cell death. Further, any induction of cell death by IFN- $\alpha$ treatment was not observed either by a counting of absolute numbers of floating dead cells or by a staining of adherent cells by trypan blue (data not shown). To further evaluate effects of IFN- $\alpha$ on A549 proliferation characteristics the analysis of cell distribution in different cell cycle phases was performed. Interestingly, no differences in cell distribution in G1, S and G2/M phases were observed among control cells and cells treated with different concentrations of IFN- $\alpha(3000,6000$ $\mathrm{U} / \mathrm{ml}$ ) for 24,48 and $72 \mathrm{~h}$ (data not shown).

\section{Modulation of A549 cell phenotype by IFN- $\alpha$}

Further, we questioned the modulation of different aspects of A549 cell phenotype with IFN- $\alpha$ which would characterise the A549 differentiation status. Treatment of A549 cells with IFN- $\alpha$ increased ALP activity (Fig. 4). In contrast, surface

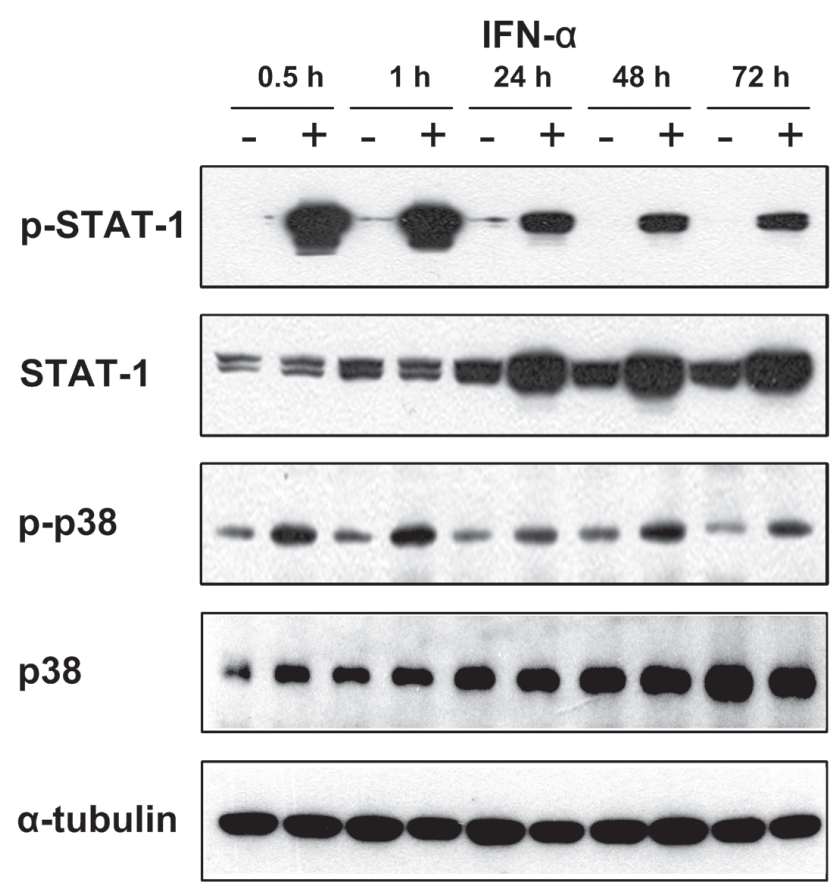

Figure 2. Phosphorylation of STAT-1 and p38 kinase after incubation of A549 with IFN- $\alpha$ for various time intervals. A549 cells were seeded $4 \mathrm{~h}$ before IFN- $\alpha$ treatment and were treated with IFN- $\alpha$ $(3000 \mathrm{U} / \mathrm{ml})$ for $0.5,1,24,48$ and $72 \mathrm{~h}$. Both phosphorylated (pSTAT-1 and p-p38) and total (STAT- 1 and p38) levels of STAT- 1 and p38 kinase together with levels of $\alpha$-tubulin were determined. Representative results from two independent experiments are shown.

expression of CD44 was not modulated by incubation of A549 cells with any of the tested IFN- $\alpha$ concentrations (500 to 6000 $\mathrm{U} / \mathrm{ml}$ ) for either 24 or $48 \mathrm{~h}$ (data not shown). Additionally, the expression and functional activity of MDR ABC transporter proteins were characterized. Unpredictably, the expression of all three evaluated proteins, i.e. ABCC1/MRP1, ABCB1/Pgp and ABCG2/BCRP, increased by incubation of A549 cells with IFN- $\alpha$ for $72 \mathrm{~h}$ (Fig. 5A). This increase in protein expression was accompanied by an increased activity of these transporter proteins measured by the ability of IFN- $a$-treated cells to exclude different fluorescent probes specific for ABCC1/MRP1 and ABCB1/Pgp transporters (calcein-AM), and ABCG2/ BCRP transporter (Hoechst 33342) (Fig. 5B). The specifity of particular fluorescent dye was tested by inhibitors of fluorescent dye exclusion. Calcein accumulation was inhibited by Sulindac and Hoechst 33342 by Fumitremorgin C (Fig. 5C).

\section{Discussion}

IFN- $\alpha$ is applied as a supportive drug in treatments of malignant diseases including lymphomas and leukemia or solid 

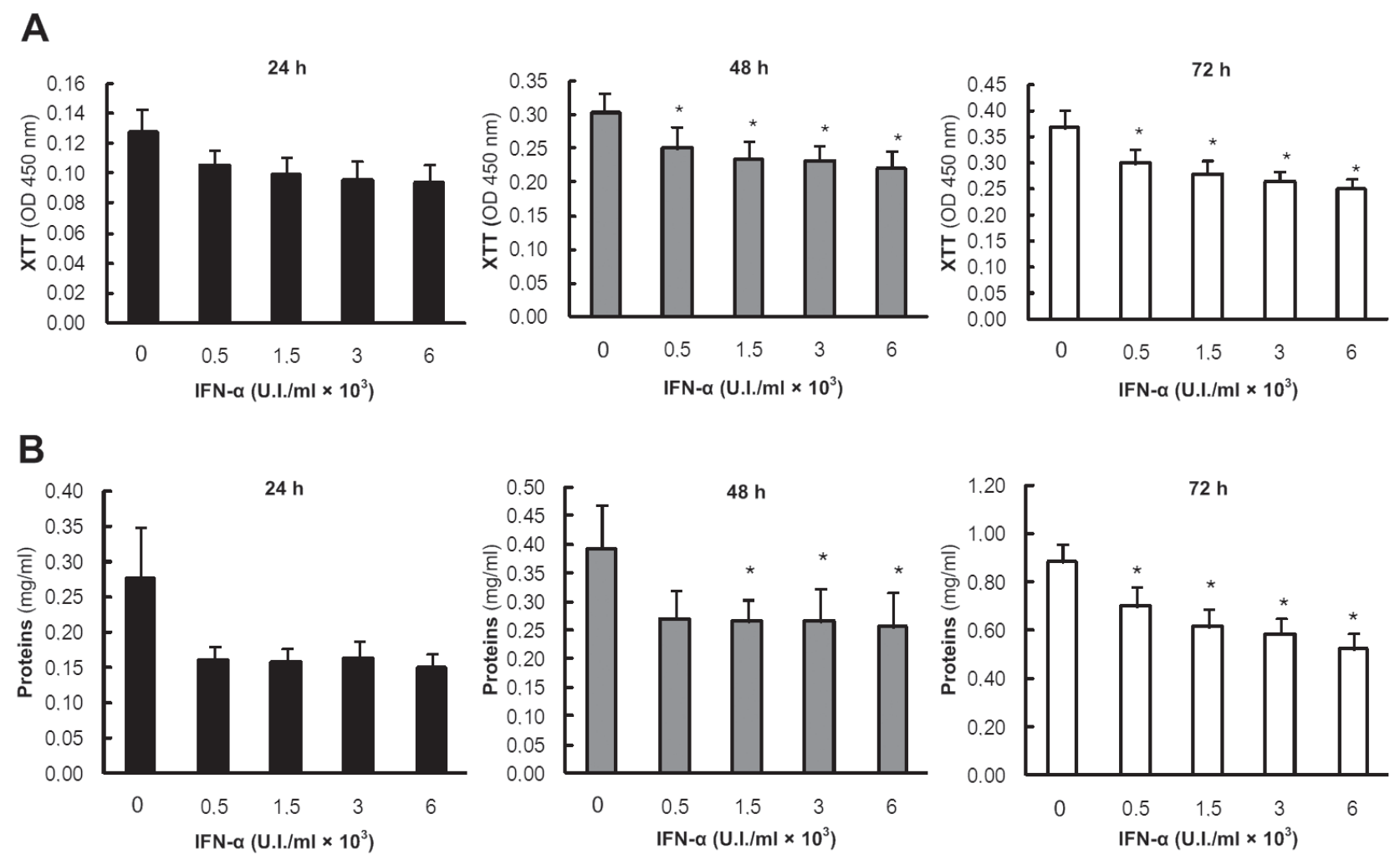

Figure 3. IFN- $\alpha$ significantly reduced proliferation of A549 cells. A549 cells were seeded $4 \mathrm{~h}$ before IFN- $\alpha$ treatment. Viability by the XTT test (A) and by determination of total protein concentration in whole cell lysates (B) was evaluated in A549 cells treated with IFN- $\alpha$ $(500,1500,3000$, and $6000 \mathrm{U} / \mathrm{ml})$ for 24,48 , and $72 \mathrm{~h}$. Data present the average \pm SEM $(n=3$ or 4$)$. Statistical differences between groups were calculated by Student's $t$-test. ${ }^{*} p<0.05$ compared with non-treated cells was considered significant.
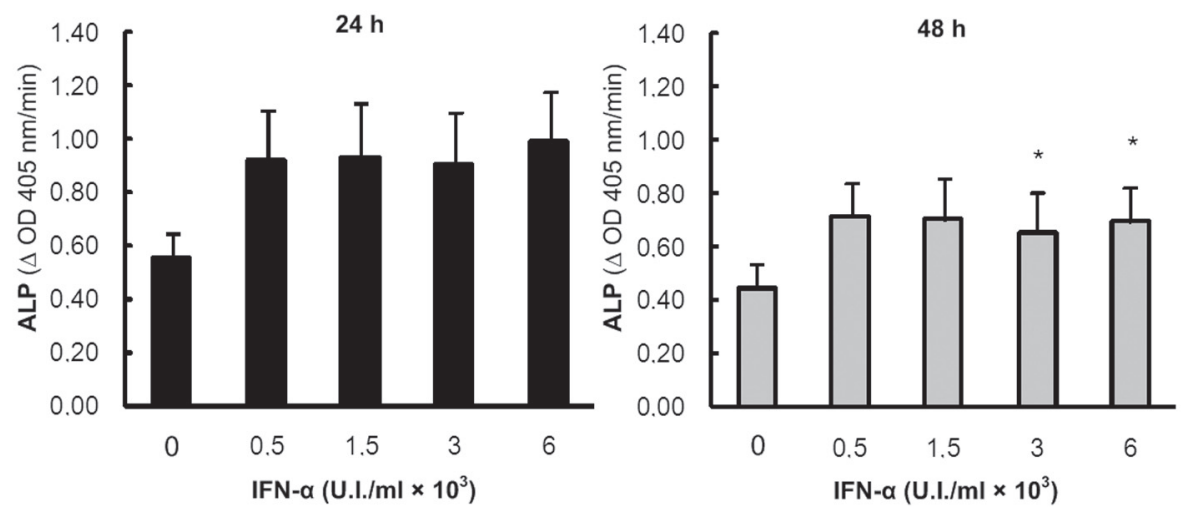

Figure 4. IFN- $\alpha$ increased alkaline phosphatase (ALP) activity in A549 cells. A549 cells were seeded 4 h before IFN- $\alpha$ treatment. ALP activity was measured in media after $24 \mathrm{~h}$ (A) and $48 \mathrm{~h}$ (B) incubation with IFN- $\alpha$. Statistical differences between the groups were calculated by Student's $t$-test. ${ }^{*} p<0.05$ compared with non treated cells was considered significant.

tumours such as melanoma and renal cancers (Jonasch and Haluska 2001). The benefit of IFN- $\alpha$ treatment is mostly limited to some neoplasms while other types are completely or partially resistant. In many cases, alternations of JAKSTAT components of the IFN- $\alpha$-induced signalling pathways could probably be proposed as mechanisms of resistance to 
A

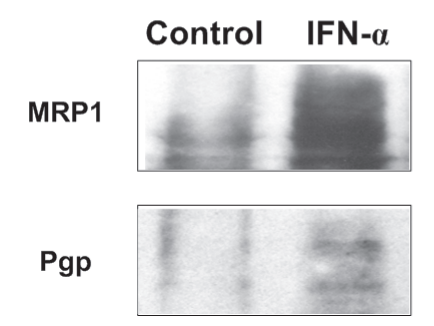

BCRP

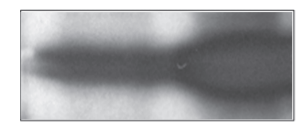

$\beta$-actin

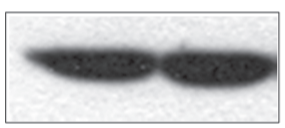

B

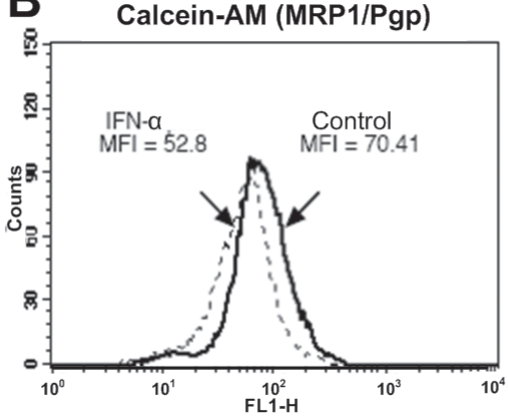

Hoechst 33342 (BCRP)

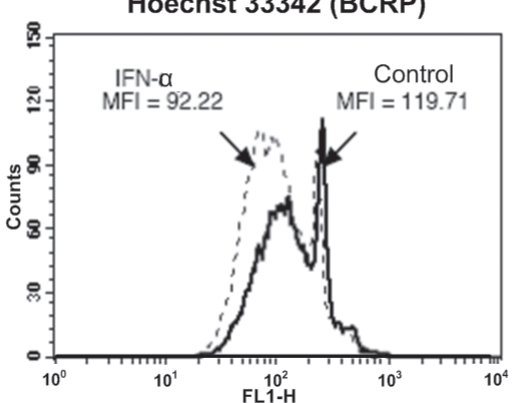

C Calcein-AM (MRP1/Pgp)

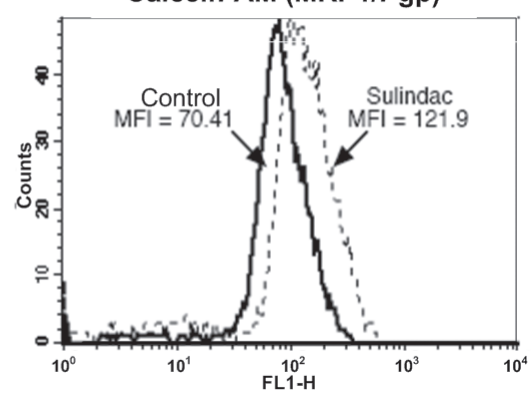

Hoechst 33342 (BCRP)

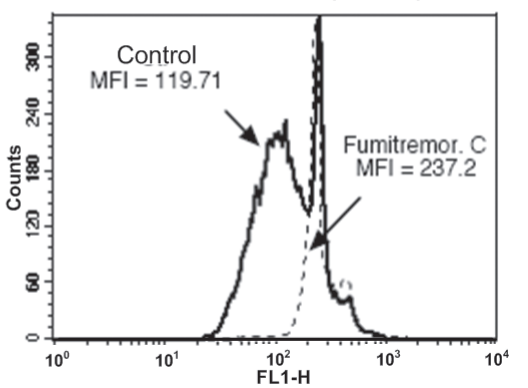

Figure 5. IFN- $\alpha$ increased expression of ABC transporter in A549 cells. A549 cells were seeded for $4 \mathrm{~h}$ and consequently treated with IFN- $\alpha(1500 \mathrm{U} / \mathrm{ml})$ for $72 \mathrm{~h}$. A. Protein expressions of ABCC1/MRP1, ABCB1/Pgp and ABCG2/BCRP were determined by Western blot analysis together with expression of $\beta$-actin. Representative results from two independent experiments are shown. B. The activity of a particular $\mathrm{ABC}$ transporter was determined with fluorescent probe characteristic for each transporter protein dependent efflux: calcein-AM (a substrate of ABCC1/MRP1 and ABCB1/Pgp), and Hoechst 33342 (a substrate of ABCG2/BCRP). The median fluorescence intensity (MFI) is shown for each population. C. The specifity of particular fluorescent dye was tested by inhibitors of fluorescent dye exclusion. Calcein-AM accumulation was inhibited by Sulindac and Hoechst 33342 by Fumitremorgin C. Representative results from at least two independent experiments are shown.

IFNs (Caraglia et al. 2005). A potential of IFN- $\alpha$ to be used as a combinational and supportive therapy for lung cancer disease was suggested in previous studies. A decrease in lung carcinoma cell proliferation with IFN- $\alpha$ was significantly elevated by other drugs such as cotylenin A, celecoxib or curcumin (Honma et al. 2003; Lee et al. 2006). However, the mechanism of the IFN- $\alpha$ effect as a single agent on lung carcinoma cells is not well understood and IFN- $\alpha$ is not generally used as a therapy for patients with lung cancer. Thus, further studies and a better evaluation of the sensitivity of different cancer cell lines and their potential to resist IFN- $\alpha$ effect are needed to clarify the frequently occurring phenomenon of neoplasm resistance to IFN- $\alpha$.

Herein, the ability of A549 cell response to IFN- $\alpha$ was clearly demonstrated by significant IFN- $\alpha$-mediated phosphorylation of STAT-1 and mitogen-activated protein kinase p38 (Fig. 1 and 2), typical transduction messengers of IFN-a signalling pathway (Caraglia et al. 2005; Lee et al. 2006). Further, IFN-a significantly inhibited A549 cell proliferation (Fig. 3). The IFN- $\alpha$-mediated inhibition of A549 cell proliferation was not accompanied either by a cell death or a cell cycle arrest in any particular cell cycle phase. This may be a result of the overall impact of IFN on cellular metabolism and differentiation, which we suggest as potential mechanisms responsible for non-cell cycle phase specific slowing cell cycle progression observed here (Jonasch and Haluska 2001).

Lee et al. (2006) observed a significant inhibitory effect of IFN- $\alpha$ on A549 proliferation only in combined treatment with celecoxib or curcumin. Further, an IFN- $\alpha$-induced change in cell phenotype was characterised. The decrease in A549 proliferation was connected with the increase in intracellular ALP activity (Fig. 3) which is suggested as a differentiation marker in various types of carcinoma cells (McCormick et al. 1995; Kovarikova et al. 2000). In contrast, IFN-a did not modulate surface expression of CD44, a receptor for hyaluronic acid playing an important role in tumour invasion and metastasis. Increased CD44 expression is suggested to be attached with the tumour cell phenotype (Dohadwala et al. 2001). Thus, it could be suggested that the IFN- $\alpha$-mediated inhibition of NSCLC cell proliferation was connected with partial A549 cell differentiation. 
Further, one of the most significant findings of this manuscript is the elevation of the protein level of selected $\mathrm{ABC}$ transporter proteins. $\mathrm{ABC}$ transporters are a family of transporter proteins that contribute to drug resistance via ATP-dependent drug efflux pumps. In humans, $48 \mathrm{ABC}$ genes have been identified to share sequence and structural homology, but only less than 10 of them are reported to confer the drug-resistant phenotype (Glavinas et al. 2004; Ozben 2006; Sarkadi et al. 2006). High levels and activity of these transporters have been observed frequently in different types of human malignancies and correlated with poor response to chemotherapeutic agents (Barančík et al. 1999; Glavinas et al. 2004; Ozben 2006). Interestingly, we observed increased protein levels of all three major $\mathrm{ABC}$ transporters Pgp, MRP1, and BCRP associated with MDR in A549 cells after IFN- $\alpha$ treatment. Simultaneously with protein levels, the IFN- $\alpha$-treated cells also increased the ability of the drug-specific $\mathrm{ABC}$ transporter-dependent efflux due to increased activity of these transporters (Fig. 4). This observation was supported by data of Mickley and colleagues, who detected increased expression of MDR-1 in differentiated cells of colon cancer, suggesting that the increase in $\mathrm{ABC}$ transporter expression and activity could be a phenomenon connected with differentiation of particular lung and colon cancer cells (Mickley et al. 1989). This is in contrast to studies suggesting an IFN- $\alpha$-mediated increase in cancer cell sensitivity to chemotherapy through downregulation of $\mathrm{ABC}$ transporter proteins (Antoniou et al. 2003; Honma et al. 2003). Currently, detailed study of this phenomena and their overall effect on drug resistance in A549 cells is in progress.

In conclusion, we documented for the first time that IFN$\alpha$-induced decrease in NSCLC proliferation was connected with modification of the NSCLC phenotype, particularly, increase in ALP activity and levels together with activities of $\mathrm{ABC}$ transporter responsible for MDR. Findings presented herein have two major significant implications. Firstly, we showed a significant modulation of A549 cell phenotype with IFN- $\alpha$ which is used in anti-tumour therapy of solid tumours alone or in combination with other drugs as discussed above. Secondly, for the first time we described a cellular in vitro experimental system in which it is possible to modify levels of selected ABC transporters (such as Pgp, MRP1 and BCRP) in lung carcinoma cell line A549 using IFN- $\alpha$, an organism-innate agent. These data contribute to our understanding of the IFN- $\alpha$ effect on carcinoma cells and potential use of IFN- $\alpha$ as a supportive therapy in the treatment of lung cancer.

Acknowledgements. This work was supported by grants from Czech Science Foundation 524/06/1197, 524/06/P345, and 31/08/ 0717 and by grants from the Academy of Sciences of the Czech Republic AV0Z50040507 and AV0Z50040702.

\section{References}

Antoniou K. M., Ferdoutsis E., Bouros D. (2003): Interferons and their application in the diseases of the lung. Chest 123, 209-216; doi:10.1378/chest.123.1.209

Barančík M., Boháčová V., Zbýňovcová M., Breier A. (1999): Differential expression of regulatory proteins in L1210/VCR cells with multidrug resistance mediated by P-glycoprotein. Gen. Physiol. Biophys. 18, 45-56

Bryja V., Pachernik J., Soucek K., Horvath V., Dvorak P., Hampl A. (2004): Increased apoptosis in differentiating p27-deficient mouse embryonic stem cells. Cell. Mol. Life Sci. 61, 1384-1400; doi:10.1007/s00018-004-4081-4

Caraglia M., Marra M., Pelaia G., Maselli R., Caputi M., Marsico S. A., Abbruzzese A. (2005): Alpha-interferon and its effects on signal transduction pathways. J. Cell. Physiol. 202, 323-335; doi:10.1002/jcp.20137

Dohadwala M., Luo J., Zhu L., Lin Y., Dougherty G. J., Sharma S., Huang M., Pold M., Batra R. K., Dubinett S. M. (2001): Non-small cell lung cancer cyclooxygenase-2-dependent invasion is mediated by CD44. J. Biol. Chem. 276, 20809-20812; doi:10.1074/jbc.C100140200

Frankova J., Kubala L., Velebny V., Ciz M., Lojek A. (2006): The effect of hyaluronan combined with KI3 complex (Hyiodine wound dressing) on keratinocytes and immune cells. J. Mater. Sci. Mater. Med. 17, 891-898; doi:10.1007/ s10856-006-0179-6

Glavinas H., Krajcsi P., Cserepes J., Sarkadi B. (2004): The role of $\mathrm{ABC}$ transporters in drug resistance, metabolism and toxicity. Curr. Drug Deliv. 1, 27-42; doi:10.2174/ 1567201043480036

Hoang T., Traynor A. M., Schiller J. H. (2002): Novel therapies for lung cancer. Surg. Oncol. 11, 229-241; doi:10.1016/ S0960-7404(02)00056-7

Honma Y., Ishii Y., Yamamoto-Yamaguchi Y., Sassa T., Asahi K. (2003): Cotylenin A, a differentiation-inducing agent, and IFN- $\alpha$ cooperatively induce apoptosis and have an antitumor effect on human non-small cell lung carcinoma cells in nude mice. Cancer Res. 63, 3659-3666

Jonasch E., Haluska F. G. (2001): Interferon in oncological practice: review of interferon biology, clinical applications, and toxicities. Oncologist 6, 34-55; doi:10.1634/theoncologist.6$1-34$

Kovarikova M., Pachernik J., Hofmanova J., Zadak Z., Kozubik A. (2000): TNF- $\alpha$ modulates the differentiation induced by butyrate in the HT-29 human colon adenocarcinoma cell line. Eur. J. Cancer 36, 1844-1852; doi:10.1016/S09598049(00)00178-7

Kvačkajová-Kišucká J., Barančík M., Breier A. (2001): Drug transporters and their role in multidrug resistance of neoplastic cells. Gen. Physiol. Biophys. 20, 215-237

Lee J., Jung H. H., Im Y. H., Kim J. H., Park J. O., Kim K., Kim W. S., Ahn J. S., Jung C. W., Park Y. S., Kang W. K., Park K. (2006): Interferon-alpha resistance can be reversed by inhibition of IFN-alpha-induced COX-2 expression potentially via STAT1 activation in A549 cells. Oncol. Rep. 15, 1541-1549

Maione P., Rossi A., Airoma G., Ferrara C., Castaldo V., Gridelli C. (2004): The role of targeted therapy in non-small 
cell lung cancer. Crit. Rev. Oncol. Hematol. 51, 29-44; doi:10.1016/j.critrevonc.2004.02.002

McCormick C., Freshney R. I., Speirs V. (1995): Activity of interferon alpha, interleukin 6 and insulin in the regulation of differentiation in A549 alveolar carcinoma cells. Br. J. Cancer 71, 232-239

Mickley L. A., Bates S. E., Richert N. D., Currier S., Tanaka S., Foss F., Rosen N., Fojo A. T. (1989): Modulation of the expression of a multidrug resistance gene ( $\mathrm{mdr}-1 / \mathrm{P}$ glycoprotein) by differentiating agents. J. Biol. Chem. 264, 18031-18040

Orlický J., Sulová Z., Dovinová I., Fiala R., Zahradníková A. Jr., Breier A. (2004): Functional fluo-3/AM assay on P-glycoprotein transport activity in L1210/VCR cells by confocal microscopy. Gen. Physiol. Biophys. 23, 357-366

Ozben T. (2006): Mechanisms and strategies to overcome multiple drug resistance in cancer. FEBS Lett. 580, 2903-2909; doi:10.1016/j.febslet.2006.02.020

Rius M., Hummel-Eisenbeiss J., Keppler D. (2008): ATP-dependent transport of leukotrienes $\mathrm{B} 4$ and $\mathrm{C} 4$ by the multidrug resistance protein ABCC4 (MRP4). J. Pharmacol. Exp. Ther. 324, 86-94; doi:10.1124/jpet.107.131342
Ruotsalainen T. M., Mattson K. (2002): Interferon trials in small cell lung cancer at one institution: a comparison of results obtained before and after initiation of systematic treatment trials using IFN-alpha in combination with other modalities. J. Interferon Cytokine Res. 22, 165-171; doi:10.1089/107999002753536130

Sandler A. B. (2003): Molecular targeted agents in non-small-cell lung cancer. Clin. Lung Cancer 5, S22-28; doi:10.3816/ CLC.2003.s.012

Sarkadi B., Homolya L., Szakacs G., Varadi A. (2006): Human multidrug resistance $\mathrm{ABCB}$ and $\mathrm{ABCG}$ transporters: participation in a chemoimmunity defense system. Physiol. Rev. 86, 1179-1236; doi:10.1152/physrev.00037.2005

Zarogoulidis K., Ziogas E., Papagiannis A., Charitopoulos K., Dimitriadis K., Economides D., Maglaveras N., Vamvalis C. (1996): Interferon alpha-2a and combined chemotherapy as first line treatment in SCLC patients: a randomized trial. Lung Cancer 15, 197-205; doi:10.1016/01695002(95)00583-8

Received: October 2, 2008

Final version accepted: February 23, 2009 